Pesq. Vet. Bras. 35(2):110-114, fevereiro 2015

DOI: $10.1590 / \mathrm{S} 0100-736 \mathrm{X} 2015000200002$

\title{
Occurrences of anti-Toxoplasma gondii and anti-Neospora caninum antibodies in sheep from four districts of Tocantins state, Brazilian Legal Amazon Region ${ }^{1}$
}

\author{
Andresa Guimarães ${ }^{2}$, Juliana M. Raimundo², Larissa M.B. Moraes ${ }^{2}$, Aline T. Silva² ${ }^{2}$ Huarrisson \\ A. Santos ${ }^{3}$, Marcos S. Pires ${ }^{4}$, Rosangela Z. Machado ${ }^{5}$ and Cristiane D. Baldani*
}

\begin{abstract}
Guimarães A., Raimundo J.M., Moraes L.M.B., Silva A.T., SantosH.A., Pires M.S., Machado R.Z. \& Baldani C.D. 2015. Occurrences of anti-Toxoplasmagondii and anti-Neospora caninum antibodies in sheep from four districts of Tocantins state, Brazilian Legal Amazon Region. Pesquisa Veterinária Brasileira 35(2):110-114. Departamento de Medicina Veterinária e Cirurgia, Instituto de Veterinária, Universidade Federal Rural do Rio de Janeiro, BR-465 Km 7, Seropédica, RJ 23890-000, Brazil. E-mail: crisbaldani@gmail.com

Toxoplasmosis and neosporosis have been recognized as economically important diseases with considerable impact on the livestock industry. Little is known concerning the occurrence of Toxoplasma gondii and Neospora caninum in sheep from Tocantins state, Brazil. Here, we investigated antibodies against these parasites and associated factors in 182 sheep from Araguaína, Santa Terezinha do Tocantins, Arguianópolis and Palmeiras do Tocantins districts, Tocantins. Sheep sera were assayed for T. gondii and N. caninum IgG antibodies by indirect fluorescence antibody test (IFAT), using cut-off point at a dilution of 1:40 and 1:25 respectively. The prevalence of seropositive animal for T. gondii was $13.74 \%$ and $13.74 \%$ for $N$. caninum. None of the characteristics studied including reproductive problems, presence of cats, presence of dogs and veterinary care $(p>0.05)$ was associated with occurrence of T. gondii or $N$. caninum infection. Only breed was identified as associated factor for the occurrence of toxoplasmosis in sheep $(\mathrm{p}<0.05)$. The present study is the first report on serum occurrence of T. gondii and N. caninum in sheep from the state of Tocantins, Brazil.
\end{abstract}

INDEX TERMS: Toxoplasma gondii, Neospora caninum, sheep, indirect fluorescent antibody test, Brazil.

RESUMO.- [Ocorrência de anticorpos anti-Toxoplasma gondii e anti-Neospora caninum em ovelhas de quatro municípios do estado do Tocantins, Região da Amazônia Legal Brasileira.] Toxoplasmose e Neosporose são reconhecidas por doenças economicamente importantes

\footnotetext{
${ }^{1}$ Received on October 9, 2014.

Accepted for publication on March 2, 2015.

${ }^{2}$ Laboratório de Patologia Clínica, Departamento de Medicina e Cirurgia Veterinária, Instituto de Veterinária (IV), Universidade Federal Rural do Rio de Janeiro (UFRRJ), BR-465 Km 7, Seropédica, RJ 23890-000, Brazil. *Corresponding author: crisbaldani@gmail.com

${ }^{3}$ Departamento de Epidemiologia e Saúde Pública, IV-UFRRJ, BR-465 Km 7, Seropédica, RJ 23890-000.

${ }^{4}$ Departamento de Parasitologia Animal, IV-UFRRJ, BR-465 Km 7, Seropédica, RJ 23890-000.

${ }^{5}$ Departamento de Patologia Veterinária, Faculdade de Ciências Agrárias e Veterinárias, Universidade Estadual Paulista (Unesp), Via de Acesso Prof. Dr. Paulo Donato Castellane s/n, Jaboticabal , SP 14884-900, Brazil.
}

com impacto considerável na indústria pecuária. Pouco se sabe sobre a ocorrência de Toxoplasma gondii e Neospora caninum em ovelhas do estado do Tocantins, Brasil. Foram investigados a ocorrência de anticorpos contra estes parasitos e fatores associados em 182 ovelhas das cidades de Araguaína, Santa Terezinha do Tocantins, Arguianópolis e Palmeiras do Tocantins, Tocantins. Os soro das ovelhas foram testados para anticorpos IgG anti-T. gondii e anti- $N$. $c a-$ ninum pela Reação de Imunofluorescência Indireta (RIFI), usando os pontos de corte na diluição de 1:40 e 1:25, respectivamente. A prevalência de animais soropositivos para T. gondii foi de $13.74 \%$ e para N. caninum, $13.74 \%$. Nenhuma das características estudadas incluindo problemas reprodutivos, presença de gatos, presença de cães e cuidados veterinários $(\mathrm{p}>0.05)$ foram associadas com a ocorrência infecção por T. gondii ou N. caninum. Somente raça foi identificada como fator associado à ocorrência de toxoplasmose em ovelhas $(\mathrm{p}<0.05)$. 0 presente trabalho é o primeiro rela- 
to da ocorrência sérica de T. gondii e $N$. caninum em ovelhas do estado do Tocantins, Brasil.

TERMOS DE INDEXAÇÃO: Toxoplasma gondii, Neospora caninum, ovelhas, Reação de Imunofluorescência Indireta, Brasil.

\section{INTRODUCTION}

Toxoplasma gondii and Neospora caninum are two closely related protozoan parasites that are distributed worldwide, although genetically and antigenically distinct (Dubey et al. 1988). They have similar life-cycles with different definitive hosts, being domestic and free-ranging felids (Frenkel et al. 1970) for Toxoplasma and dogs, coyotes and gray wolf (McAllister et al. 1998, Gondim et al. 2004, Dubey et al. 2011) for Neospora. Common intermediate hosts including a wide range of mammals are reported (Dubey 1999, Tenter et al. 2000).

Toxoplasmosis has economic relevance to both veterinary and human medicine (Buxton et al. 1998, Hillet al 2005). The protozoan is an important causative agent of reproductive failure, as embryonic death and absorption, abortion, fetal mummification and stillbirth in animals and man (Aspinall et al. 2002). In small ruminants, infection not only results in significant reproductive losses, but also has implication for public health since consumption of infected meat is an important source of infection of this zoonotic agent (Bisson et al. 2000). Ubiquitous domestic cats are probably the major source of contamination as they commonly produce and excretelarge amount of oocystsin its feces (Dubey et al. 2004). However, dogs have been associated as a potential risk factor for T. gondii infection in humans due to mechanical transmission of oocysts (Lindsay et al. 1997).

Neospora caninum is a recently recognized protozoan parasite and until the eighties it was misdiagnosed as T. gondii due to morphological similarities (Dubey et al. 1988). Nowadays it is recognized as a cause of abortions in cattle and neuromuscular disorder in dogs (Dubey1999). Although natural infection by $N$. caninum in sheep is not common, clinical manifestations are similar to toxoplasmosis (Buxton et al. 1998). Abortion, neonatal mortality and clinical signs in adult sheep have been reported (Bishop et al. 2010). Additionally, transplacental transmission of $N$. caninum in sheep should be considered, especially in the etiology of abortion (West et al. 2006).

Recent surveys conducted in Brazil showed that there is a variation in occurrence of anti-T. gondii and anti- $N$. caninum in sheep from different states. In São Paulo state, southeastern region of Brazil, seropositivity for T. gondii and $N$. caninum was $34.7 \%$ and $9.2 \%$, respectively (Figliuolo et al. 2004); in 2012, in the same state, Andrade et al. observed $12.8 \%$ seropositives for $N$. caninum in sheeps. Soares et al. (2009) in Mossoró, Rio Grande do Norte, reported an overall occurrence of $20.7 \%$ for T. gondii and $1.8 \%$ for N. caninum. Similar results were observed by Ueno et al. (2009) in sheep from Federal District, central region of Brazil, in which $38.22 \%$ of the animals were seropositive for T. gondii and $8.81 \%$ for $N$. caninum. In Sergipe, Mendonça et al. (2013) observed that $28.22 \%$ of the ovine samples were serum-reactive to T. gondii. For N. caninum, Langoni et al.
(2011) obtained $13.1 \%$ in serological surveys conducted in sheep from farms in Minas Gerais state, southeastern region, and Faria et al. (2010) in Alagoas state, northeastern region, observed occurrencerate of $9.6 \%$ in sheep.

The Brazilian Legal Amazon (BLA) region is a new frontier, where agricultural sustainable development and sheep activity has been attempted. The state of Tocantins is a developing area in the BLA and although livestock activity is primary, sheep production has increased greatly in the past years. Despite toxoplasmosis and neosporosis in sheep has been reported worldwide, there is no information about T. gondii and N. caninum from Tocantins state. Recently Moraes et al. (2011) reported a occurrence of $18.75 \%$ and $4.69 \%$ for T. gondii and $N$. caninum respectively in sheep from Maranhão state, a border-line state, suggesting the presence of the agents in the region of BLA.

In view of the growing importance of sheep in Brazil and the possible economic losses due to toxoplasmosis and neosporosis, the present study aimed to determine the occurrence of anti- $N$. caninum and anti- $T$. gondii antibodies in sheep in the state of Tocantins, where no information to date is available.

\section{MATERIALS AND METHODS}

The study was conducted in eight farms of the mesoocidental region of Tocantins state, in sheep of the municipality of Aragua-

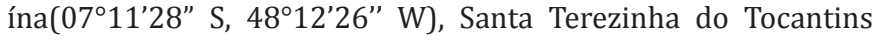

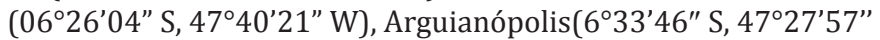
W) and Palmeiras do Tocantins (6 $6^{\circ} 36^{\prime} 46.01^{\prime \prime}$ S, 47 $\left.32^{\prime} 44.88^{\prime \prime} W\right)$. The climate of the area is semi-humid tropical. The temperature varies from 32 to $20^{\circ} \mathrm{C}$.

Farms were selected based upon easy access and owner agreement on collecting blood samples. The sheep sampled were of different breeds and ages. However, details about those parameters were not possible to acquire with precision and were not considered in this study. A total of 182 samples were collected, being $36(19,80 \%)$ male and $146(80,22 \%)$ female. Blood samples were collected from the jugular vein and serum was harvested following centrifugation of clotted blood and stored at -20C until serologic being performed.

A comprehensive questionnaire, which focused on risk factors for toxoplasmosis and neosporosis, was given to each farm owner whose herd was sampled. The information collected included animal's sex, herd characteristics, the management system, veterinary assistance, sanitary care, reproductive problems history, and the presence of domestic cats or dogs according to Thrusfield (2004).

Detection of anti-Toxoplasma gondii and anti-Neospora caninum antibodies were performed by Indirect Immunofluorescence Assay (IFAT), as previously described by Camargo et al. (1964) and Mineo (2007), respectively. Tachyzoites of the T. gondii RH strain obtained by intraperitoneal serial passages in Swiss mice and tachyzoites of $N$. caninum(Nc-1 strain) maintained by continuous passages in cultures of VERO cells were used as antigen. A cut-off dilution of 1:40 and 1:25 were used for T. gondii and $N$. caninum, respectively (Moraes et al. 2011). In each IFAT reaction, previously established positive and negative sera samples were included as controls and a FITC-conjugated monoclonal anti-sheep IgG (Sigma-Aldrich ${ }^{\circledR}$ - F5137) secondary antibody was used.

Statistical analysis was performed using Exact Fisher test, with $95 \%$ confidence interval and estimation error of 0.05 . We have considered as significant a $P$-value of $\leq 0.05$. 


\section{RESULTS}

From a total of 182 serum samples, 25 (13.74\%) were positive for Toxoplasma gondii and the occurrence among herds ranged from $5.66 \%$ to $35.29 \%$. Antibodies were detected in 24 female $(13.19 \%)$ and only one male $(0.55 \%)$. Out of the eight inspected farms, six (87.5\%) had at least one seropositive animal for T. gondii.

For Neospora caninum, the frequency of antibodies was $13.74 \%(25 / 182)$ by the IFAT at dilution 1:25. Anti-N.caninum antibodies of diagnostic value were detected in six farms sampled, with occurrence values ranging from $5 \%$ to $53.85 \%$. Considering gender, antibodies anti-N.caninum were detected in $19(10.43 \%)$ female and $6(3.30 \%)$ male sheep.

Only five $(2.75 \%)$ animals, all female, were positive for both agents, and two of them belonged to properties with history of reproductive problems. Sheep herd were negative for T. gondii and N. caninum in only one farm.

All farm owners answered to the questionnaire. Among them, six reported presence of cats on the farm and seven reported the presence of dogs. History of abortion was observed in six farms. All farms had extensive management and sheep were raised for meat and milk consumption. In seven farms presence of veterinary assistance was reported.

The results of the association among variables and occurrence for toxoplasmosis and neosporosis in sheep are summarized in Table 1. The presence of anti-T. gondii and anti- $N$. caninum antibodies were not associated with reproductive problems, presence of dogs and cats, or veterinary assistance $(p>0.05)$ in the set of the farms studied. However, when gender was on the focus, association for T. gondii was observed in females $(\mathrm{p}<0.05)$.

\section{DISCUSSION}

Toxoplasma gondii infection has been recognized as a significant cause of ovine perinatal mortality and reproductive failure for at least 50 years (Hartley \& Marshall 1957). Production of sheep is an important economic activity for several families in Tocantins state, but data regarding the occurrence of toxoplasmosis in Brazilian Legal Amazon (BLA) region are really scarce. The overall occurence of to- xoplasmosis is Brazil ranges from $3.3 \%$ to $52.05 \%$, depending on the serological test employed, sample size, region studied and cutoff of the tests (Moura et al. 2007, Lopes et al. 2010). In the present study, $13.74 \%$ of the animals presented antibodies anti-T. gondii, which is similar to $17.5 \%$ found in São Paulo State by Oliveira-Sequeira et al. (1993) and $18.75 \%$ observed in Bahia State by Pita Gondim et al. (1999) in Brazil. Similar results were also obtained worldwide with $16.2 \%$ in Noruega (Skjerve et al. 1998) and $12 \%$ in Chile (Gorman et al. 1999). This is the first report on serum frequency of $T$. gondii in sheep from the state of Tocantins. In this regard, there is only another report of toxoplasmosis among sheep in the BLA region, where a similar occurrence of $18.75 \%$ were reported in Maranhão state (Moraes et al. 2011).

The results of the present work could be explained, at list in part, due to the extensive management system of the animals, once sheep raised in this system have greater probability of coming into contact with oocysts (Waltner-Toews et al. 1991,Lopes et al. 2010), although no significant association was observed between occurrence of T. gondii and the presence of cats in the herds. Additionally, it was confirmed the relevance of the weather in the occurrence of toxoplasmosis in sheep, since T. gondii oocysts survive longer in warm-moist than in cold dry atmospheres, as shown by Fleck (1972) and Fayer (1981). Therefore, differences in location and climate, management of the sampled animals, serological tests and cut-off values should also be considered.

Gender was significantly associated with T. gondii infected animals on the farms, which corroborates the findings of Clementino et al. (2007) and Van der Puije et al. (2000), demonstrating that female sheep are more susceptible than male. In contrast, two reports suggested no correlation between gender and the presence of anti-T. gondii antibodies (Romanelliet al. 2007, Caballero-Ortega et al. 2008). The lack of association between seropositivity for T. gondii and herds with abortion problems was also reported by Soares et al. (2009) and Silva et al. (2003) in Brazil. However, all of the six farms in which reproductive problems had been reported, there were sheep seropositive to anti-T. gondii antibodies, suggesting that $T$. gondii could be the causative agent of the sporadic abortion reported by some farmers.

Table 1. Distribution of sheep seropositive for Toxoplasma gondii and Neospora caninum from Tocantins State, Brazil, detected by Indirect Immunofluorescence (IFAT)

\begin{tabular}{|c|c|c|c|c|c|c|c|c|}
\hline \multirow[t]{2}{*}{ Variables } & & \multirow{2}{*}{$\begin{array}{c}\text { Total } \\
\text { tested }\end{array}$} & \multicolumn{3}{|c|}{ Toxoplasma gondii } & \multicolumn{3}{|c|}{ Neospora caninum } \\
\hline & & & $\begin{array}{c}\text { № } \\
\text { positive }\end{array}$ & $\begin{array}{c}\% \\
\text { positive }\end{array}$ & $\mathrm{P}^{\mathrm{a}}$ & $\begin{array}{c}\text { № } \\
\text { positive }\end{array}$ & $\begin{array}{c}\% \\
\text { positive }\end{array}$ & $\mathrm{P}^{\mathrm{a}}$ \\
\hline \multirow[t]{2}{*}{ Gender } & Female & 146 & 24 & 16.44 & 0.03 & 19 & 13.01 & 0.59 \\
\hline & Male & 36 & 1 & 2.78 & & 6 & 16.67 & \\
\hline \multirow[t]{2}{*}{ Herds with abortion problems } & Yes & 114 & 23 & 14.11 & 0.75 & 24 & 14.72 & 0.32 \\
\hline & No & 68 & 2 & 10.53 & & 1 & 5.26 & \\
\hline \multirow[t]{2}{*}{ Presence of cats } & Yes & 122 & 17 & 13.93 & 0.90 & 16 & 13.11 & 0.90 \\
\hline & No & 60 & 8 & 13.33 & & 9 & 15.00 & \\
\hline \multirow[t]{2}{*}{ Presence of dogs } & Yes & 152 & 23 & 15.13 & 0.26 & 23 & 15.13 & 0.26 \\
\hline & No & 30 & 2 & 6.67 & & 2 & 6.67 & \\
\hline \multirow[t]{2}{*}{ Veterinary assistance } & Yes & 132 & 17 & 12.88 & 0.76 & 22 & 16.67 & 0.10 \\
\hline & No & 50 & 8 & 16.00 & & 3 & 6.00 & \\
\hline
\end{tabular}

a Fisher's exact test. 
With respect to the presence of cats, no statistical difference was observed ( $>>0.05$ ) for T. gondii in the studied herd and, in addition, seropositive sheep had been also observed in properties where there were no cats. Similar results were found by Soares et al. (2009), although Lopes et al. (2010) reported a positive association among this variable, indicating that the presence and intimate contact with feline species is important in the epidemiology of toxoplasmosis. In addition, Romanelli et al. (2007) observed that the number of cats present at the farm is a crucial factor for seropositive rate of $T$. gondii. Considering that in the present study the number of cats in each farm was not accessed, it is possible that the results were herein influenced.

The frequency of antibodies against $N$. caninum observed in the present study (13.74\%) was next to the positivity rate obtained in serological surveys conducted in sheep from farms in Minas Gerais (13.1\%) and São Paulo state (12.8\%), southeastern Brazil (Langoni et al. 2011, Andrade et al. 2012). Serological studies in Brazil have presented a variety of results according to the region studied. Concerning about BLA region, the highest occurrence for $\mathrm{N}$. caninum was reported by Aguiar et al. (2004) in sheep from Rondônia state (29\%), while frequency of $5 \%$ was found by Moraes et al. (2011) in the state of Maranhão. Although comparison of frequencies of infection between regions are difficult, differences could be due to sampling methods employed herein. Rossi et al. (2011), in a study of neosporosis using different serological methods, suggest that variations among frequencies rate may also be due to differential environment contamination and climatic conditions. Indeed, regions that present high annual rainfall index, such as Rondônia state, present higher occurrence rate for $\mathrm{N}$. $\mathrm{Ca}$ ninum. Results of the present study could also be related to the extensive management system of the animals, evidencing the low technical level of sheep production, what is in agreement with data reported by Faria et al. (2010). In addition, results can vary according to the degree of canine presence and age of the animals. Although no significant association between dogs presence and $N$. caninum infection was observed ( $p>0.05)$, Al-Majali et al. (2008) identified the presence of more than one dog in the herd as a risk factor for neosporosis.

None of the variables analyzed (gender, reproductive problems history, presence of domestic cats or dogs and veterinary assistance) demonstrated significant association with $N$. caninum (Table 1 ). The lack of association ( $\mathrm{p}>0.05$ ) between sheep seropositive for $N$. caninum and gender has also been observed in previous studies in Brazil (Romanelli et al. 2007, Ueno et al. 2009, Salaberry et al. 2010), demonstrating that male and female are equal susceptible to infection. In this study, no significant association between herds with abortions and $N$. caninum $(\mathrm{p}>0.05)$ was observed. Additionally, there was no statistical difference $(p>0,05)$ when presence of dogs was analyzed, which is consistent with Romanelli et al. (2007) findings. However, seven farms included in this study owned dogs and sheep seropositive for $N$. caninum was found in six farms. The present study shows, for the first time, the occurrenceof $T$. gondii and $N$. caninum in sheep from the state of Tocantins, northern region of Brazil and adds new information on the epidemiology of ovine toxoplasmosis and neosporosis in the Brazilian legal Amazon region. Thus, further investigations are needed in order to know the actual role played by toxoplasmosis and neosporosis on economic losses of sheep breeding in that region.

\section{REFERENCES}

Aguiar D.M., Chiebao D.P., Rodrigues A.A.R., Cavalcante G.T., Labruna M.B. \& Gennari S.M. 2004. Prevalência de anticorpos anti-Neospora caninum em ovinos do município de Monte Negro, RO, Amazônia Ocidental Brasileira. Arqs Inst. Biológico, São Paulo, 7:616-618.

Al-Majali A.M., Jawasreh K.I., Talafha H.A. \& Talafha A.Q. 2008. Neosporosis in sheep and different breeds of goats from Southern Jordan: prevalence and risk factors analysis. Am. J. Anim. Vet. Sci. 3(2):47-52.

Andrade G.D., Bruhn F.R., Rocha C.M., De Sá Guimarães A., Gouveia A.M. \& Guimarães A.M. 2012. Seroprevalence for Neospora caninum in goats of Minas Gerais state, Brazil. Res. Vet. Sci. 12:331-333.

Aspinall T.V., Marlee D., Hyde J.E. \& Sims P.F.G. 2002. Prevalence of Toxoplasma gondii in commercial meat products as monitored by polymerase chain reaction - food for thought? Int. J. Epidemiol. 32:1193-1199.

Bishop S., King J., Windsor P., Reichel M.P., Ellis J. \& Slapeta J. 2010. The first report of ovine cerebral neosporosis and evaluation of Neospora caninum prevalence in sheep in New South Wales. Vet. Parasitol. 170:137-142.

Bisson A., Maley S., Rubaire-Akiiki C.M. \& Wastling J.M. 2000. The seroprevalence of antibodies to Toxoplasma gondii in domestic goats in Uganda. Acta Trop. 76:33-38.

Buxton D., Maley S.W., Wright S., Thomson K.M., Rae A.G. \& Innes E.A. 1998. The pathogenesis of experimental neosporosis in pregnant sheep. J. Comp. Pathol. 118:267-279.

Caballero-Ortega H., Palma J.M., García Márquez L.J., Gildo-Cárdenas A. \& Correa D. 2008. Frequency and risk factors for toxoplasmosis in ovines of various regions of the State of Colima, Mexico. Parasitology 135:13851389.

Camargo M.E. 1964. Improved technique of indirect immunofluorescence for serological diagnosis of toxoplasmosis. Revta Inst. Med. Trop. 6:117-118.

ClementinoM.M., Souza M.F. \& Neto V.F. 2007. Seroprevalence and Toxoplasma gondii-IgG avidity in sheep from Lajes, Brazil. Vet. Parasitol. 146:199-203.

Dubey J.P., Carpenter J.L., Speer C.A., Topper M.J. \& Uggla A. 1988. Newly recognized fatal protozoan disease of dogs. J. Am. Vet. Med. Assoc. 192:1269-1285.

Dubey J.P. 1999. Recent advances in Neospora and neosporosis. Vet. Parasitol. 84:349-367.

Dubey J.P., Navarro I.T., Sreekumar C., Dahl E., Freire R.L., Kawabata H.H., Vianna M.C., Kwok O.C., Shen S.K., Thulliez P. \& Lehmann T. 2004. Toxoplasma gondii infections in cats from Paraná, Brazil: seroprevalence, tissue distribution, and biologic and genetic characterization of isolates. J. Parasitol. 90:721-726.

Dubey J.P., Jenkins M., Rajendran C., Miska K., Ferreira L.R., Martins J., Kwok O.C.H. \& Choudhary S. 2011. Gray wolf (Canis lupus) is a natural definitive host for Neospora caninum. Vet. Parasitol. 181:382-387.

Faria E.B., Cavalcanti E.F., Medeiros E.S., Pinheiro Junior J.W., Azevedo S.S., Athayde A.C. \& Mota R.A. 2010. Risk factors associated with Neospora caninum seropositivity in sheep from the State of Alagoas, in the Northern region of Brazil. J. Parasitol. 96(1):197-199.

Fayer R. 1981. Toxoplasmosis update and public health implications. Can. Vet. J. 22:344-352.

Figliuolo L.P.C., Kasai N., Ragozo A.M.A., De Paula V.S.O., Dias R.A., Souza S.L.P. \& Gennari S.M. 2004. Prevalence of anti-Toxoplasma gondii and anti-Neospora caninum antibodies in ovine from São Paulo State, Brazil. Vet. Parasitol. 123:161-166.

Fleck D.G. 1972. The seroepidemiology of Toxoplasma infection in man. Proc. Royal Society of Medicine 65:1002. 
Frenkel J.K., Dubey J.P. \& Miller N.L. 1970. Toxoplasma gondii in cats: fecal stages identified as coccidian oocysts. Science 167:893-896.

Gondim L.F.P., Barbosa Jr H.V., Ribeiro Filho C.H. \& Saeki H. 1999. Serological survey of antibodies to Toxoplasma gondii in goats, sheep, cattle and water buffaloes in Bahia State, Brazil. Vet. Parasitol. 82:273-276.

Gondim L.F.P., McAllister M.M., Pitt W.C. \& Zemlicka D.E. 2004. Coyotes (Canis latrans) are definitive hosts of Neospora caninum. Int. J. Parasitol. 34:159-161.

Gorman T., Pablo Arancibia J., Lorca M., Hird D. \& Alcaino H. 1999. Seroprevalence of Toxoplasma gondii infection in sheep and alpacas (Llama pacos) in Chile. Prev. Vet. Med. 40:143-149.

Hartley W.J. \& Marshall S.C. 1957. Toxoplasmosis as a cause of ovine perinatal mortality. N. Z. Vet. J. 30:119-124.

Hill D.E., Chirukandoth S. \& Dubey J.P. 2005. Biology and epidemiology of Toxoplasma gondii in man and animals. Anim. Health Res. Rev. 6:4161.

Langoni H., Greca Jr H., Guimarães F.F., Ullmann L.S., Gaio F.C., Uehara R.S., Rosa E.P., Amorim R.M. \& Silva R.C. 2011. Serological profile of Toxoplasma gondii and Neospora caninum infection in commercial sheep from São Paulo State, Brazil. Vet. Parasitol. 177(1/2):50-54.

Lindsay D.S., Dubey J.P., Butler J.M. \& Blagburn B.L. 1997. Mechanical transmission of Toxoplasma gondii oocysts by dogs. Vet. Parasitol. 73:27-33.

Lopes W.D., Santos T.R., Silva R.S., Rossanese W.M., Souza F.A., Faria Rodrigues J.D., Mendonça R.P., Soares V.E. \& Costa A.J. 2010. Seroprevalence of and risk factors for Toxoplasma gondii in sheep raised in the Jaboticabal microregion, São Paulo State, Brazil. Res. Vet. Sci. 88:104-106.

Mendonça C.E., Barros S.L., Guimarães V.A., Ferraudo A.S. \& Munhoz A.D. 2013. Prevalence and risk factors associated to ovine toxoplasmosis in northeastern Brazil. Revta Bras. Parasitol. Vet. 22(2):230-234.

McAllister M.M., Dubey J.P., Lindsay D.S., Jolley W.R., Wills R.A. \& McGuire A.M. 1998. Dogs are definitive hosts of Neospora caninum. Int. J. Parasitol. 28(9):1473-1478.

Mineo T.W.P. 2007. Estudo da resposta imune celular e humoral de cães frente à infecção oral por Neospora caninum. Tese de Doutorado, Universidade Estadual Paulista, São Paulo, SP. 171p.

Moraes L.M., Raimundo J.M., Guimarães A., Santos H.A., Macedo Junior G.L., Massard C.L., Machado R.Z. \& Baldani C.D. 2011. Occurrence of anti-Neospora caninum and anti-Toxoplasma gondii IgG antibodies in goats and sheep in western Maranhão, Brazil. Revta Bras. Parasitol. Vet. 20(4):312-317.

Moura A.B., OsakiS.C., Zulpo D.L. \& Marana E.R.M. 2007. Ocorrência de anticorpos contra Toxoplasma gondii em suínos e ovinos abatidos no município de Guarapuava, PR, Brasil. Revta Bras. Parasitol. Vet. 16:54-56.

Oliveira-Sequeira T.C.G., Amarante A.F.T., Salata E. \& Sogayar R. 1993. Se- rological survey for Toxoplasma infection in sheep in São Paulo State, Brazil. Vet. Zootec. 5:121-125.

Romanelli P.R., Freire R.L., Vidotto O., Marana E.R., Ogawa L., De Paula V.S.O., Garcia J.L. \& Navarro I.T. 2007. Prevalence of Neospora caninum and Toxoplasma gondii in sheep and dogs from Guarapuava farms, Paraná State, Brazil. Res. Vet. Sci. 82:202-207.

Rossi G.F., Cabral D.D., Ribeiro D.P., Pajuaba A.C., Corrêa R.R., Moreira R.Q., Mineo T.W., Mineo J.R. \& Silva D.A. 2011. Evaluation of Toxoplasma gondii and Neospora caninum infections in sheep from Uberlândia, Minas Gerais State, Brazil, by different serological methods. Vet. Parasitol. 175(3/4):252-259.

Salaberry S.R., Okuda L.H., Nassar A.F., Castro J.R. \& Lima-Ribeiro A.M. 2010. Prevalence of Neospora caninum antibodies in sheep flocks of Uberlândia county, MG. Revta Bras. Parasitol. Vet. 19(3):148-151.

Silva A.V., Pereira E.L., Meireles L.R., Gottschalk S., Mota R.A. \& Langoni H. 2003. Toxoplasmose em ovinos e caprinos: estudo soroepidemiológico em duas regiões do Estado de Pernambuco, Brasil. Ciência Rural 33(1):115-119.

SilvaK.L.M.V. \& De la Rue M.L. 2006. Possibilidade da transmissão congênita de Toxoplasma gondii em ovinos através de seguimento sorológico no município de Rosário do Sul, RS, Brasil. Ciência Rural 36:892-897.

Skjerve E., Waldeland H., Nesbakken T. \& Kapperud G. 1998. Risk factors for the presence of antibodies to Toxoplasma gondii in Norwegian slaughterlambs. Prev. Vet. Med. 35:219-227.

Soares H.S., Ahid S.M., Bezerra A.C., Pena H.F., Dias R.A. \& Gennari S.M. 2009. Prevalence of anti-Toxoplasma gondii and anti-Neospora caninum antibodies in sheep from Mossoró, Rio Grande do Norte, Brazil. Vet. Parasitol. 160:211-214.

Tenter A.M., Heckeroth A.R. \& Weiss L.M. 2000. Toxoplasma gondii: from animals to humans. Int. J. Parasitol. 30(12-13):1217-1258.

Thrusfield M. 2004. Epidemiologia Veterinária. 2a ed. Roca, São Paulo. 556 .

Ueno T.E.H., Gonçalves V.S.P., Heinemann M.B., Dilli T.L.B., Akimoto B.M., Souza S.L.P., Gennari S.M. \& Soares R.M. 2009. Prevalence of Toxoplasma gondii and Neospora caninum infections in sheep from Federal District, central region of Brazil. Trop. Anim. Health Prod. 41:547-552.

Van der Puije W.N., Bosompem K.M., Canacoo E.A., Wastling J.M. \& Akanmori B.D. 2000. The prevalence of anti-Toxoplasma gondii antibodies in Ghanaian sheep and goats. Acta Tropica 76:21-26.

Waltner-Toews D., Mondesire R. \& Menzies P. 1991. The seroprevalence of Toxoplasma gondii in Ontario sheep flocks. Can. Vet. J. 32(12):734-737.

West D.M., Pomroy W.E., Collett M.G., Hill F.I., Ridler A.L., Kenyon P.R., Morris S.T. \& Pattison R.S. 2006. A possible role for Neospora caninum in ovine abortion in New Zealand. Small Rumin. Res. 62:135-138. 